\title{
Língua e discurso em Flusser e Foucault: um diálogo à espreita?
}

\section{Marcos N. Beccari}

Doutor; Universidade Federal do Paraná, Curitiba, PR, Brasil

contato@marcosbeccari.com

\section{Resumo}

Este ensaio, de caráter heurístico, propõe uma aproximação conceitual entre Flusser e Foucault, particularmente entre o primeiro livro de Flusser e a chamada fase arqueológica de Foucault. Após uma breve contextualização do panorama estruturalista ao qual ambos buscavam responder, são apresentadas quatro "cenas", ou recortes temáticos, que preparam um diálogo que nunca existiu. O diálogo é traçado em torno da noção da palavra enquanto matéria irredutível a partir da qual o pensamento e a realidade podem se dar. Por fim, defende-se que, enquanto Foucault visava desnaturalizar as palavras, Flusser tratava de retraduzi-las, como um meio de amplificar a realidade.

\section{Palavras-chave}

Vilém Flusser. Michel Foucault. Língua. Discurso. Pósestruturalismo.

\section{Introdução}

Propor um diálogo entre Flusser e Foucault implica, de saída, tentar contornar uma questão intransponível: tais pensadores não apenas apresentam interesses distintos, trajetórias peculiares e vocabulários demarcatórios, mas antes de tudo modos singulares de escrita e expressão. 0 valor da tentativa, no entanto, consiste em revelar que tais diferenças, se postas em perspectiva, coadunam-se em torno de uma prerrogativa em comum, algo que Deleuze e Parnet certa vez assim assinalaram: "As relações são exteriores a seus termos." (1998, p. 69). Flusser e Foucault buscaram demonstrar, cada qual ao seu modo, a exterioridade das relações que perfazem as conjunções heterogêneas entre palavras, modelos, práticas etc. Tal registro relacional opera deslocando os termos e reenviando a realidade a uma dispersão de fundo que lhe é imanente. 
A aproximação ora ensaiada detém-se nas reflexões em torno da linguagem e do discurso que marcaram, na França, os primeiros livros de Foucault e, no Brasil, a inserção de Flusser no debate filosófico, com a publicação de Língua e Realidade. Nesse livro inaugural, o autor desvia-se deliberadamente do velho problema da relação da linguagem para com uma realidade referencial - problema que, de Platão a Wittgenstein, é constitutivo da filosofia ocidental. Não interessava a Flusser, por exemplo, resolver a questão nominalista segundo a qual a linguagem é inapta em explicar sua relação com o mundo, uma vez que não podemos sair nem da linguagem nem do mundo para observar como se relacionam. Essa contenda pressupõe que a língua de algum modo se refere à realidade, ao passo que, para o filósofo brasileiro, a língua é realidade. Eis como as relações são, em Flusser, exteriores a seus termos: o mundo não pode ser separado da língua que o enreda e que, ao mesmo tempo, nos permite conhecê-lo' ${ }^{1}$.

Por sua vez, Foucault conduzia uma "ontologia do presente", isto é, sobre as condições a partir das quais emergem e se atualizam as formas vigentes de pensamento e moralidade. Assim, em vez de se indagar acerca da referencialidade entre linguagem e realidade, Foucault (2007) localiza a questão no seio do pensamento clássico:

Tais modos de decifração provém de uma situação clássica da linguagem - aquela que reinou no século XVII, quando o regime dos signos se tornou binário e quando a significação foi refletida na forma da representação. (FOUCAULT, 2007, p. 61).

Importa-nos pontuar que, assim como Flusser, Foucault não se servia de qualquer princípio último, nem mesmo da contingência histórica, para explicar determinado estado de coisas; em vez disso, seu pensamento se delineava em busca de conexões possíveis entre enunciados dispersos. Afinal, sabendo que todo discurso forja seus próprios termos e critérios, Foucault gostava de evidenciar esse ato forjador (no duplo sentido que o termo comporta) enquanto manobra indissociável dos modos pelos quais compreendemos as coisas.

Embora Flusser tenha se posicionado filosoficamente como Bodenlos (sem chão, sem descendência) devido ao desenraizamento em relação à sua cultura materna, é notório que,

\footnotetext{
10 problema metafísico, por exemplo, que conduz à dúvida cartesiana sobre como saber se nossos pensamentos se adequam às coisas tal como elas são em si mesmas só faz sentido porque pressupõe desde o início a cisão entre res cogitans (coisa pensante) e res extensa (coisa externa), como se fossem duas substâncias independentes. Já para Flusser, se a língua/intelecto e a realidade/extensão são o mesmo, elas não podem não se adequar, e o problema da referencialidade é simplificado à “[...] correspondência entre frases ou pensamentos, resultando das regras da língua." (FLUSSER, 2007, p. 46).
} 
ao publicar seu primeiro livro, Língua e Realidade, em 1963, ele sabia em que chão estaria a pisar, considerando o panorama europeu e norte-americano dos estudos linguísticos e literários no início da década de 1960. Já se encontrava difundida a noção estrutural segunda a qual a língua pode não servir apenas para descrever o mundo, sendo antes o que, a partir de sua estrutura, o constitui. Com efeito, o que estava em jogo era, de um lado, o apogeu da linguística saussuriana e, de outro, particularmente no cerne do debate intelectual francês, as possibilidades de ruptura contra ela ${ }^{2}$ - o que no campo das artes se projetava como prova constante de desestabilização da linguagem e, ao mesmo tempo, como esforço de ultrapassá-la por meio da dissolução das convenções de representação ${ }^{3}$. Nesse período, Foucault (2014, p. 77) já se debruçava, ainda que "de uma forma bastante hesitante e, sobretudo no início, sem controle metódico suficiente", sobre suas primeiras investigações arqueológicas, isto é, voltadas às tramas histórico-discursivas dos saberes tais como História da loucura, $O$ nascimento da clínica (publicado no mesmo ano que Língua e Realidade) e As palavras e as coisas.

Uma vez delineado brevemente o cenário intelectual ao qual Flusser e Foucault buscavam responder, apresento a seguir quatro "cenas", ou recortes temáticos, que preparam um diálogo que nunca existiu - ou que não fora registrado ${ }^{4}$. A primeira cena trata da imagem recorrente do gesto de tecer; a segunda, do entrelaçamento epistemológico entre duas maneiras de pensar o "como pensar"; a terceira, do horizonte ontológico da língua; a quarta, do devir demiúrgico pleiteado por ambos os pensadores. 0 diálogo é então traçado em torno da noção da palavra enquanto matéria irredutível a partir da qual o pensamento e a realidade podem se dar. Por fim, defendo que Flusser e Foucault traçaram caminhos distintos de um mesmo fluxo de desnaturalização e retradução do mundo.

\section{Cena 1: A imagem da tessitura}

Ciente do debate intelectual vigente, Flusser publicou, um ano antes de seu livro inaugural, o "Ensaio para um estudo do significado ontológico da língua" na Revista

\footnotetext{
2 Barthes figurou um nome emblemático nesse contexto: ele ganha visibilidade, inicialmente, enquanto intelectual estruturalista ligado ao pensamento de Saussure; mas sua trajetória é marcada, no decorrer da década de 1950, por uma reviravolta, sendo doravante enquadrado no rol dos críticos pós-estruturalistas. Tal vertente, por sua vez, pode ser associada a um texto inaugural de Derrida (2009), publicado em 1960: A estrutura, o signo e o jogo no discurso das ciências humanas.

3 Ver Foster (2014, p. 79-98)

${ }^{4}$ De acordo com Bento Prado Jr. (1999), Flusser estava presente nas aulas que Foucault ministrara na USP, em 1965, acerca de As palavras e as coisas (publicada no ano seguinte). Mas, por falta de outras informações ao meu alcance, assumo que o diálogo entre Flusser e Foucault nunca existiu.
} 
Brasileira de Filosofia, onde o intelectual estreante faz coro ao que identifica como um clamor contemporâneo por uma "visão integral da 'realidade"” (1962, p. 70). Se o argumento central do artigo ainda se alinhava ao mote estruturalista segundo o qual a realidade não pode ser pensada sem o recurso da língua, Flusser avança radicalmente em Língua e Realidade, cuja tese passa ser a de que cada língua, ao realizar-se, realiza a realidade. Significa que tudo se torna real ao se realizar, isto é, ao ser apreendido (em alusão ao verbo anglofônico to realize) pelos intelectos que participam da realidade. 0 ensaio que precede $o$ livro, outrossim, já continha uma pista incisiva: após mencionar o fato de a raiz latina res ("coisa") ter se perdido na língua portuguesa, Flusser recorre ao termo wirklichkeit, que "quer dizer 'realidade' em alemão", e assinala que, embora também signifique "surtir efeito" e "funcionar", originalmente denotava "tecer" (FLUSSER, 1962, p. 74-75). Haveria, então, um vínculo perdido entre o realizar, o instaurar realidades e a tessitura, analogia que reaparece em Língua e Realidade, quando Flusser compara o intelecto a "uma fiação que transforma algodão bruto (dados dos sentidos) em fios (palavras). A maioria da matéria-prima, porém, já vem em forma de fios" (FLUSSER, 2007, p. 49).

No âmbito dos estudos linguísticos já apartados, nos anos 1960, do estruturalismo, tornou-se corrente a metáfora da "rede de nós", ou de uma "malha do discurso", ou ainda de um emaranhado de fios que se cruzam $^{5}$. Em diversos momentos, com efeito, Foucault também lançava mão dessa imagem - como em As palavras e as coisas, ao referir-se ao pensamento clássico como "aquele que trama todos os fios entrecruzados da 'representação em quadro' [e que] jamais se encontra lá presente" (FOUCAULT, 2007, p. 425); ou em $A$ arqueologia do saber, ao definir o enunciado "[...] como um grão que aparece na superfície de um tecido de que é o elemento constituinte." (FOUCAULT, 2014, p. 96). No imaginário épico, diga-se de passagem, a imagem de um entrelaçamento por meio do qual se enredam o mundo, os sujeitos e os sentidos remonta o fazer de Penélope (da Odisseia) que, diante das suposições da morte de seu marido em batalha e das pressões para que se casasse novamente, estabeleceu, como condição para um novo enlace, a infindável tessitura de um tapete a ser tecido durante o dia e desfeito durante a noite.

A sutura do mundo enquanto linguagem também desponta em Nietzsche, que teria sido, segundo Foucault, "o primeiro a aproximar a tarefa filosófica de uma reflexão radical sobre a linguagem" (FOUCAULT, 2007, p. 420). Em seu texto Sobre a verdade e a mentira no

\footnotetext{
5 De acordo com Maria Cristina L. Ferreira (2003, p. 44), referindo-se ao quadro atual da Análise de Discurso no Brasil, “[...] já se tornou lugar comum usar a expressão 'tecido discursivo' ou 'tessitura' para falar-se de discurso", metáfora que "abre lugar para o não-sistêmico, o não-representável.” (FERREIRA, 2003, p. 44).
} 
sentido extra-moral, de 1876, Nietzsche (2000) argumenta que a linguagem não procede de uma adequação entre palavras e coisas, mas engendra um processo metafórico que é posto em movimento antes mesmo do gesto de dar nome às coisas. Essa textualidade do mundo humano presume uma base poética imanente, uma vontade inventiva que opera no fundo de cada palavra ou discurso e que constitui uma dimensão anterior às significações e aos modelos de representação entranhados na linguagem. Enquanto convenção, por sua vez, a língua se institui a partir do momento em que o intelecto se esquece desse vínculo metafórico com o mundo e, com a aquisição e a manutenção de hábitos seculares, admite como natural aquilo que, em sua gênese, teria sido o produto de uma vontade. É com esse raciocínio que Nietzsche consegue deslocar a língua de qualquer essencialidade e situar sua imanência na tessitura do real - deslocamento que, a meu ver, vigora tanto no pensamento de Foucault quanto no de Flusser.

\section{Cena 2: Duas maneiras de pensar o "como pensar"}

Como se sabe, a ideia de que não podemos conhecer diretamente a realidade é recorrente na tradição filosófica. Pode ser associada, por exemplo, à crítica kantiana da razão, isto é, à restrição dos fenômenos ao que pode ser pensado pelo sujeito. Para Flusser (2007), porém, não há um sujeito transcendental, com suas formas a priori de conhecimento que filtram e configuram as coisas, pois o sujeito sequer se constituiria sem a mediação de uma língua: "No íntimo sentimos que somos possuídos por ela [a língua], que não somos nós que a formulamos, mas que é ela que nos formula" (FLUSSER, 2007, p. 37). Na epistemologia flusseriana, portanto, não se trata mais de saber o que significa o sujeito, mas o modo (ou modos) pelo qual ele se constitui - abandono do "que(m)" e "por que" em favor do "como". E se Kant postulara que o pensamento está sempre pressuposto na percepção dos fenômenos, Foucault, por sua vez, interpretou a manobra kantiana como a maior tentativa de realizar o sonho da cultura moderna de querer encontrar na razão humana o fundamento do próprio humano. 0 pensador francês então "inverte", grosso modo, a manobra kantiana contra si mesma, mostrando como o sujeito do conhecimento e as próprias formas do conhecimento também são pressupostos a priori: 
[...] atemo-nos a esse sujeito de conhecimento, a este sujeito da representação, como ponto de origem a partir do qual o conhecimento é possível e a verdade aparece. Seria interessante tentar ver como se dá, através da história, a constituição de um sujeito que não é dado definitivamente, que não é aquilo a partir do que a verdade se dá na história, mas de um sujeito que se constitui no interior mesmo da história, e que é a cada instante fundado e refundado pela história. É na direção desta crítica radical do sujeito humano pela história que devemos nos dirigir. (FOUCAULT, 2002, p. 11).

Foucault depurou inicialmente a premissa clássica de que, para que exista um "sujeito" (um eu, uma identidade), é preciso que o mesmo esteja representado6. E quando esse sujeito se depara com sua própria representação, com "os olhares aos quais ela se oferece, os rostos que torna invisíveis, os gestos que a fazem nascer" (FOUCAULT, 2007, p. 20), ele percebe que o conhecimento de si e de todas as coisas não remete a um dado prévio ao próprio conhecimento - eis a virada para a episteme moderna. Para Flusser, vimos que não há sujeito anterior à língua, mas sua tese parece radicalizar a questão, a ponto de igualar a realidade à língua, ou, melhor, às diversas línguas: "a língua [...] é igual à totalidade daquilo que é apreendido e compreendido, isto é, a totalidade da realidade" (FLUSSER, 2007, p. 201). Não porque a realidade seja determinada ou ordenada linguisticamente e, portanto, que a língua seja algo de transcendente, mas porque o mundo é vivido em forma de língua, isto é, como conjunto de símbolos que podem ser apreendidos e compreendidos por nós, humanos. Em seu ensaio que precede Língua e Realidade, Flusser já oferecia um esboço geral dessa tese:

\begin{abstract}
Não quero afirmar, "a priori", que a "realidade" está dentro da língua e exclusivamente dentro dela. Afirmo, isto sim, que a realidade aparece exclusivamente em forma de língua. A língua, venha ela de fora ou de dentro, significa a realidade, pois, ela é, em seu conjunto, um sistema de símbolos que significam a realidade. Tudo o que os sentidos externos e o sentido introspectivo nos fornecem precisa vestir-se em trajes lingüísticos para ser apreendido e compreendido. (FLUSSER, 1962, p. 71).
\end{abstract}

Ocorre, é claro, que Flusser e Foucault não falavam da mesma coisa: o primeiro compreendia a língua como dimensão que possibilita ontologicamente todos os processos de significação, enquanto Foucault tinha em mente algo anterior à língua, algo que a

\footnotetext{
6 Esta é a problemática que abre As palavras e as coisas, quando Foucault (2007, p. 3-21) analisa a pintura Las Meninas de Velázquez: nesse quadro, o pintor nos observa na medida em que nos encontramos no lugar de seu modelo, e o que era para ser só observado passa a observar quem o observa.
} 
circunscreve e a regula - o discurso. Tal noção foucaultiana designa basicamente todas as condições necessárias para que algo tenha valor/significado, de modo que as diversas formas de linguagem (verbal, textual, visual etc.), seus elementos estruturais e recursos retóricos são entendidos como dados discursivos. Pressupõe-se, assim, que valores e significados não preexistem aos discursos; são os discursos que produzem um objeto significativo, situando-o em relação a outros objetos, valores e significados.

[Trata-se de] interrogar a linguagem, não na direção a que ela remete, mas na dimensão que a produz; negligenciar o poder que ela tem de designar, de nomear, de mostrar, de fazer aparecer, de ser o lugar do sentido ou da verdade e, em compensação, de se deter no momento - logo solidificado, logo envolvido no jogo do significante e do significado - que determina sua existência singular e limitada. Trata-se de suspender, no exame da linguagem, não apenas o ponto de vista do significado (o que já é comum agora), mas também o do significante, para fazer surgir o fato de que em ambos existe linguagem, de acordo com domínios de objetos e sujeitos possíveis, de acordo com outras formulações e reutilizações eventuais. (FOUCAULT, 2014, p. 126).

Sob esse prisma, não há, de um lado, língua e, de outro, os fatos, tomados como entes verdadeiros em si próprios, mas apenas proposições de "verdade" em permanente disputa. É uma visada, portanto, que se opõe ao chamado núcleo rígido da Linguística e da Semiótica na medida em que não pressupõe, para os processos de significação, um conjunto sistemático de regras e propriedades formais ${ }^{7}$. Por sua vez, a concepção flusseriana de língua nada tem a ver com uma tal urdidura (JÚNIOR; CAPELA, 2016). Flusser oscila, não obstante, entre um sentido mais estrito e outro mais dilatado de "língua": refere-se, por exemplo, tanto a idiomas flexionais e aglutinantes quanto a uma dimensão ontológica que funda realidades. E, nesse aspecto ampliado, não resta qualquer dicotomia entre ser e nãoser, mas somente a fluidez de um vir-a-ser concomitante à língua, ao intelecto e à realidade. Ou seja, em última instância não interessava tanto a Flusser definir com precisão níveis ontológicos - o real, o indizível, a poesia, a conversação etc. -, mas sim o modo como eles coexistem e estão correlacionados.

Convém assinalar ainda que, nos termos de Debora Pazetto Ferreira (2018,), tanto em Nietzsche quanto em Flusser (e, acrescento, também em Foucault), “A vontade humana [...] cria o mundo e depois interessa-se por conhecer sua obra, descobrindo, por fim, a si mesma

\footnotetext{
7 Na concepção de Maldidier (2003, p. 31), a perspectiva de geral da chamada Análise de Discurso, desde o seu surgimento no quadro epistemológico francês, "[...] repousa sobre a intuição muito forte de que [os discursos] não podem visar às sistematicidades da língua como um contínuo de níveis.” (MALDIDIER, 2003, p. 31).
} 
no fundo do mundo. Ela também cria o intelecto e depois o analisa, descobrindo a si mesma no fundo do intelecto" (FERREIRA, 2018, p. 49). Por isso que, em A história do diabo, de 1965, Flusser (2008) propõe uma analogia entre a vontade humana e uma aranha que secreta, como teia, a língua-realidade. No caso de Foucault, essa questão aparece com mais clareza a partir de $A$ vontade de saber, de 1976, em que a genealogia do governo dos outros conjuga-se com a do governo de $\mathrm{si}^{8}$. Ou seja, Foucault passa a refletir sobre certas práticas, denominadas "técnicas de si", pelas quais os sujeitos se relacionam consigo mesmos e, assim, se constituem como agentes morais - identificando-se como quem vive como louco, como trabalhador, como culpado etc. Essas práticas que nos sujeitam, mas que não nos determinam, revelam que a vontade humana não apenas resulta como produto das redes de saber/poder, mas antes as instaura em sua torção íntima, proporcionando tanto jogos de verdade quanto um lugar de invenção de si.

Nota-se, pelo exposto, que Flusser e Foucault podem suscitar, por caminhos díspares, algumas conclusões convergentes. Quais sejam: (1) toda realidade supõe certa concepção do que é a realidade e de como é possível pensá-la; (2) as tramas linguístico-discursivas são ao mesmo tempo a causa e o efeito de um intelecto capaz de conhecer, organizar e se situar no mundo; (3) a investigação ou explicitação desse processo não é alheio a ele, mas inerente; (4) é a vontade humana que nos move a forjar realidades, tanto quanto a indagar como tais realidades foram forjadas. Ainda assim, considerando o escopo específico de Língua e Realidade e da chamada fase arqueológica de Foucault, o paralelo até aqui projetado pode soar forçado, uma vez que as duas perspectivas, por mais que se alinhem em certos aspectos, contrastam em muitos outros - sobretudo no que tange ao interesse dos autores. De um lado, Foucault queria pensar de outro modo como chegamos a ser o que somos; de outro, Flusser buscava compreender o que é que nos permite pensar de outro modo.

\footnotetext{
80 trabalho investigativo de Foucault foi por ele inicialmente denominado "arqueologia", quando mirava a produção dos saberes, e depois "genealogia", quando focou o poder. Em sua fase genealógica (a partir da década de 1970), o exercício do poder passa a explicar a produção dos saberes. Mais do que uma forma de coerção ou repressão, o poder é o que, por meio de disposições discursivas, produz os saberes - o saber jurídico, por exemplo, ao realizar as práticas penais, como o inquérito, produz verdades acerca do indivíduo culpado. A "verdade dos fatos" é, por conseguinte, o produto discursivo do poder de distinguir "fatos verdadeiros". Mas, a partir da década de 1980, Foucault desloca a análise do poder para os modos de subjetivação, revelando-os como condições das relações entre poder e saber.
} 


\section{Cena 3: Duas faces de um mesmo horizonte ontológico}

Claro está que, enquanto o estruturalismo pretendia descobrir universalidades subjacentes (na linguagem, na cultura, no inconsciente etc.), Flusser descartara desde o início a existência de qualquer estrutura de fundo. Pensava a língua, antes, em termos de um agenciamento disperso de realidades. Do mesmo modo, Foucault nunca pretendeu identificar uma força oculta que atravessasse os estratos de saber e as relações de poder. Suas questões, afinal, não aludiam a totalidades, mas justamente a singularidades: por que em determinada época e lugar emergiram certas práticas e não outras? Que enunciados específicos possibilitaram a produção de determinados saberes? Quais são os saberes que autorizam esta ou aquela prática? Portanto, ali onde outros pensadores buscaram depreender ordens, estruturas e naturezas, Foucault e Flusser viam nada mais que construções humanas que ora emergem ora desaparecem.

Mas os dois pensadores se opunham ao estruturalismo de maneiras distintas. De um lado, Foucault procurava reconstruir atrás dos "fatos" toda uma rede de discursos, poderes, estratégias e práticas, operando assim uma desnaturalização do mundo. De outro, Flusser mirou na potência fabuladora que instaura nossa experiência de mundo - por isso sua concepção positiva da língua, algo como uma atividade plástica: no lugar do eidos (essência, estrutura), o plasma, a elaboração, a fabricação. Demarcada tal distinção, Língua e Realidade, embora se distancie da empresa arqueológica ${ }^{9}$, dialoga parcialmente com o interesse pontual que Foucault dedicara à linguagem literária, assunto que logo abandonaria ${ }^{10}$. Numa conferência de 1964, Foucault define a linguagem como “o murmúrio de tudo que é pronunciado [...] [abrangendo] tanto o fato das palavras acumuladas na história quanto o próprio sistema da língua" (FOUCAULT, 2005, p. 140), sendo a literatura "o lugar essencial da linguagem, sua origem sempre repetível" (FOUCAULT, 2005, p. 174). No geral, Foucault sublinha o caráter repetível da literatura - como "repetição contínua da biblioteca, da impureza já letal da palavra" (p. 146), onde "se ouve o infinito do murmúrio, o amontoamento das palavras já ditas" (p. 153) - e conclui que:

\footnotetext{
9 Do ponto de vista de As palavras e as coisas, por exemplo, pode-se dizer que a tese de Flusser sobre a língua não retoma a episteme clássica, pois não encara a língua como ordenação e representação direta do mundo; e também não permanece no regime discursivo do pensamento moderno, pois não se ampara em um sujeito transcendental como a priori a partir do qual é possível pensar o mundo.

${ }^{10}$ Em entrevista ao jornalista Roger Pol Droit (2008, p. 61-69), de 1975, Foucault explica que, na década anterior, ainda sob influência de Blanchot e Barthes, a literatura lhe parecia ser a expressão de algo que os outros discursos eram incapazes de formular, levando à ideia de que a linguagem literária só pode ser analisada a partir de si própria. Após $A$ arqueologia do saber, contudo, Foucault passa a valorizar os discursos não-literários, direcionando-se depois aos dispositivos nãodiscursivos.
} 
[...] a linguagem é talvez o único ser absolutamente repetível que existe no mundo. [...] Sem dúvida, um dia será preciso fazer a análise de todas as formas de repetição possíveis que há na linguagem. E talvez seja na análise dessas formas de repetição que se poderá esboçar algo como uma ontologia da linguagem. Digamos agora simplesmente que a linguagem não cessa de se repetir. (FOUCAULT, 2005, p. 160).

Flusser, em contrapartida, enquanto imigrante que pensava e escrevia em múltiplas línguas, preocupava-se menos com as repetições e mais com as metamorfoses entre as línguas, o que o fez considerar a tradução como um problema filosófico fundamental. É nesse sentido que em Língua e Realidade vemos tantos exemplos de não-equivalência entre termos e expressões que supostamente designariam uma mesma coisa. Trata-se de mostrar que as diferentes línguas (incluindo suas variantes musicais, literárias etc.) constituem cada qual um universo próprio, ao mesmo tempo em que, todavia, podem dialogar e se expandir num mesmo horizonte poroso de conversação.

Ao situar, aliás, a conversação num "horizonte geográfico", Flusser não queria agrupar as línguas em termos de uniformidade (todas no mesmo nível), mas sim como realidades que, em suas singularidades, alastram-se pela permeabilidade da tradução, passando ao largo da verticalidade linguístico-estrutural. Essa horizontalidade da conversação pareceme análoga ao que Deleuze e Guattari chamaram de rizoma (as múltiplas raízes de uma planta), como noção relacional daquilo que se encontra no meio, entre as coisas: "Entre as coisas não designa uma correlação localizável que vai de uma para outra e reciprocamente, mas uma direção perpendicular, um movimento transversal que as carrega uma e outra" (DELEUZE; GUATTARI, 1995, p. 36). Em outros termos, o rizoma designa as conexões (entre o solo e a árvore, por exemplo) e não uma estrutura ou um conjunto delimitado, do mesmo modo que a conversação desenhada por Flusser demarca um entremeio ou um interstício entre as línguas, e não algum tipo de paridade ou totalidade.

\section{Cena 4: 0 devir demiúrgico}

O que interessa a Flusser, com efeito, são as conexões que se produzem no próprio devir da língua, um devir demiúrgico, engendrador de realidades. Pois a língua cria o mundo não apenas no sentido de organizá-lo, significá-lo ou dissimulá-lo, mas antes como fluxo incessante de realidades distintas. Logo, o que há para ser apreendido, dito e compreendido sobre o mundo é o próprio modo pelo qual nos relacionamos com ele, ou seja, as realidades 
que as línguas tecem e engendram. Não é que nossa relação com o mundo resulte da língua, mas sim que tal relação é a própria língua, como artifício que instaura realidades simultaneamente singulares e plurais.

Tal propriedade demiúrgica que Flusser atribui à língua remete ao que Barbara Cassin, em seu estudo sobre os sofistas, chamou de efeito-mundo: "o ser da ontologia nada mais é do que um efeito do dizer" (CASSIN, 2005, p. 34). Não seria ocioso lembrar, nesse sentido, que a retórica sofística "não argumenta a partir do verdadeiro, mas do verossímil (eikos)" (REBOUL, 2004, p. 4). Admitindo a verdade como resultado de um consenso, um efeito de discurso, a prática dos sofistas (enquanto logógrafos, espécie de escrivães públicos) pode ser associada aos aspectos que entendemos hoje por literários, uma vez que a arte sofística incorporava elementos que antes eram próprios da poesia: figuras de linguagem, prosa narrativa, recursos de persuasão etc. Ora, é curioso observar ainda que, de acordo com Foucault, na supracitada conferência de 1964, a retórica teria se apagado em prol do aparecimento literário:

[...] ao mesmo tempo que diz uma história, que conta algo [a literatura] deverá a cada momento mostrar, tornar visível o que é literatura, o que é a linguagem da literatura, pois a retórica, outrora encarregada de dizer o que deveria ser a bela linguagem, desapareceu. (FOUCAULT, 2005, p. 147).

Claro que, todavia, Flusser não tinha em mente esse tipo de afinidade entre poesia, retórica e literatura; mas considero quase inevitável encarar Língua e Realidade a partir de certa retoricidade ontológica. A tese, afinal, de que a língua constitui, forma, cria e propaga realidades (axiomas que compõem os títulos dos capítulos deste livro) remonta - em que pese o salto anacrônico - a concepção de Górgias, sofista siciliano, acerca da linguagem. Um dos principais argumentos de seu Elogio de Helena, como se sabe, referia-se à soberania da linguagem, capaz não só de persuadir e suscitar emoções, mas também de fabricar o mundo humano: “[...] o lógos [significando aqui palavra, linguagem, discurso] é um grande soberano que, por meio do menor e mais inaparente dos corpos, realiza os atos mais divinos [...]" (GÓRGIAS, 2005, p. 52). A palavra é soberana porque enreda o universo humano, que é um universo edificado pela linguagem. Resta em Górgias, portanto, uma proto-ontologia do "vir a ser", isto é, do que passa a existir na medida em que é dito, a partir das diversas maneiras pelas quais é possível dizer. 
Pois bem, mas é Foucault quem certamente diria que um pensador da antiguidade grega tem algo a nos dizer hoje. E ainda no que se refere ao Elogio de Helena, Foucault talvez ressaltasse que a noção gorgiana de linguagem aparece indissociável da discursividade que orienta a palavra: "Pois o discurso que persuade cria uma necessidade na alma que ele persuade, de ser, a uma só vez, persuadida pelas coisas que são ditas e condescendente face às coisas que são feitas." (GÓRGIAS, 2005, p. 65). Significa que, concomitante ao que se diz, sempre resta uma dimensão discursiva atuando de maneira normativa e reguladora e que, em vez de fundar "de imediato" o mundo, situa-nos nele por meio da produção de saberes, de estratégias e de práticas. Não se trata de opor linguagem e discurso, mas justamente de afirmar o caráter concomitantemente linguístico e discursivo dos fatos e saberes - o que equivale, em termos sofísticos, à materialidade da palavra. Tanto é que, ao ser indagado se seria pertinente colocá-lo "ao lado dos sofistas (verossimilhança) e não dos filósofos (a palavra da verdade)", Foucault (2002, p. 140) responde: "Ah, nisso estou radicalmente ao lado dos sofistas".

[Pois] para eles, a prática do discurso não é dissociável do exercício do poder. [...] parece-me igualmente importante nos sofistas essa ideia de que o logos, enfim, o discurso, é algo que tem uma existência material. [...] Ora, lá ainda, o logos platônico tende a ser cada vez mais imaterial, mais imaterial que a razão - a razão humana. Então a materialidade do discurso, o caráter factual do discurso, a relação entre discurso e poder, tudo isso me parece um núcleo de ideias que eram profundamente interessantes, que o platonismo e o socratismo afastaram totalmente, em proveito de uma certa concepção do saber. (FOUCAULT, 2002, p. 140-141).

\section{0 diálogo: a materialidade da palavra}

Enquanto Flusser teorizava sobre os entrelaçamentos entre língua e realidade, Foucault interrogava a respeito das condições de emergência de certos discursos em detrimento de outros, inclusive daqueles acerca da linguagem. Portanto, em vez de concordar ou discordar de Flusser, creio que o filósofo francês provavelmente se contentaria em apontar as tramas discursivas que condicionam e culminam em Língua $e$ Realidade. A propósito de tal seara, em As palavras e as coisas Foucault observa que, antes da segunda metade do século XIX, as teorias tendiam a explicar não o que é a linguagem, mas antes como nos servimos dela para transmitir ideias, representar o pensamento, veicular significações - subsumindo, assim, a definição clássica de linguagem. A partir de então, 
através de uma série de movimentos que passam por disciplinas como a linguística e por experiências poéticas como as de Mallarmé, tornou-se pertinente questionar não só o que é a linguagem, mas também quais são seus limites, suas capacidades, sua materialidade. "Parece-me que temos aí, ao abordar o problema da materialidade da linguagem, uma espécie de volta ao tema da sofística." (FOUCAULT, 2002, p. 158).

Ao seu modo, entrementes, Foucault situava-se nesse mesmo recuo a um viés materialista de mundo (não no sentido marxista, mas naquele de Demócrito, passando pelos sofistas e epicuristas). Pois, em primeiro lugar, se Foucault operava em termos arqueológicos era por tratar a palavra escrita enquanto "prova material" de como determinado objeto constituiu-se a partir da articulação entre diferentes discursos, e também de como esses discursos se relacionavam entre si, fabricando de maneira dispersa e fragmentada alguma configuração epistêmica coerente. Em segundo lugar, isso nada tem a ver com descrições paradigmáticas gerais, em termos historicamente abstratos. Foucault nos remete, em vez disso, a uma antiga concepção ontológica de átomos que jorram e se chocam ao acaso: trata-se de reconstituir os jogos de saber/poder que produziram o aparecimento e o apagamento de enunciados, acontecimentos e coisas. São os discursos, afinal, que definem ao mesmo tempo os limites e as formas de dizibilidade, do que é pensável e, portanto, do que é concreto. 0 que está em questão para Foucault é, em última análise, a irrupção de singularidades não necessárias: a aparição da loucura, a emergência da razão humana, as práticas de enclausuramento etc.

Mais do que suspeitar das evidências induzidas pelas verdades estabelecidas, Foucault escavava questões e problemas que ele desejava pensar, explicitando como cada tipo de discurso não se isola dos demais, mas permanece em inflexão nas redes de inteligibilidade do mundo. Por isso que o registro discursivo lhe importava mais que o linguístico, cuja aparente natureza formal e repetível talvez lhe fizesse alusão ao que já se sabe, a uma maneira normal de se pensar. No caso da língua-realidade de Flusser, no entanto, não resta qualquer "natureza" linguística. Em Língua e Realidade, afinal, a questão de fundo é a tradução como manancial ontológico das múltiplas línguas que, por não se equivalerem em nenhuma instância, constituem a matéria irredutível a partir da qual o pensamento e a realidade podem se dar. Desde o início, portanto, o diálogo entre Flusser e Foucault não se coloca em termos do que é linguístico ou discursivo, mas sim em termos de uma antiga e dispersa ontologia que admite como materiais (porque provenientes de tessituras, ainda que inventadas) as expressões singulares que compõem uma realidade múltipla. E ao passo 
que Foucault era antes de tudo cético, Flusser já demarcava um ecletismo filosófico que, tal como um pagão disposto a aceitar todos os deuses sem se devotar a nenhum deles, esforçase por resguardar a intrigante noção da língua enquanto "a mais antiga e a mais recente obra de arte" (2007, p. 37).

\section{Poslúdio: Desnaturalizar e retraduzir}

Após deixar o Brasil em meados da década de 1970, Flusser passou a debruçar-se sobre questões mais pontuais do presente, tecendo reflexões que o tornariam reconhecido como pioneiro no debate filosófico acerca do mundo digital, da cibernética, da cultura midiática etc. Assim, justamente num momento em que o estruturalismo já deixava de suscitar grandes discussões, o autor de Língua e Realidade foi acolhido como um intelectual de referência na Europa, antes de sê-lo no Brasil. Por sua vez, o interesse de Foucault deslocou-se da arqueologia à genealogia, o que assinala mais precisamente o abandono metodológico das epistemes, enquanto configurações estritamente discursivas, em prol da noção mais ampla de dispositivo, que engloba elementos discursivos e não-discursivos (instituições, técnicas, condições político-econômicas etc.), formando-se na intersecção entre as relações de poder e as relações de saber. Foucault traçava, a partir de então, novos mapas do presente: se antes as práticas e saberes revelavam descontinuidades discursivas, agora tal dispersão passa a indiciar o exercício do poder, com sua lógica própria, suas gramáticas, sua materialidade e sua razão.

Mas nunca houve qualquer tipo de reviravolta no pensamento de Flusser e de Foucault; ambos avançaram a partir do seu próprio itinerário, percorrendo domínios diversos com prodigiosa propriedade. Se Foucault prosseguia reavaliando o passado, era por insistir em encará-lo como novo, como uma redescrição ontológica do presente. Só que tal ontologia opera como que inversamente: trata-se de reler os textos do mundo para desfazer as tessituras, para desrealizar o mundo, desatando sua naturalidade em prol da consistência das relações que se abrem pelos textos. A filosofia de Foucault não pretende explicar a existência, e sim deslocá-la mediante certas invisibilidades expostas - pois a invisibilidade é também uma in-existência: o que "não existe" também está dentro da existência, constitui o real e nos re-situa no presente. Noutras palavras, o possível e o impossível, o existente e o inexistente se definem reciprocamente e são constantemente 
postos em jogo, (re)produzindo singularidades não necessárias - eis a materialidade foucaultiana, uma realidade possível dentre inúmeras outras.

Já a escrita de Flusser, na medida em que é metalinguística e intertextual por excelência, opera em termos de fabricação de mundo. Ao adotar, em seu primeiro livro, uma língua que lhe era estrangeira para falar de toda língua-realidade, Flusser estava determinado a aventurar-se em território incógnito, sem tradição nem inscrição prévia, um entremeio onde se possa transformar rigidez em plasticidade, numa procura lenta por clareza e permeabilidade do real no esforço mesmo de dizê-lo. Não obstante, o que se apresenta em Língua e Realidade é, mais do que uma filosofia brasileira, a contundência do sotaque flusseriano, um jeito específico de pensar a partir da falta de chão em que se imiscuem diversas línguas, tradições e interlocutores possíveis. Disso decorre que a tradução, apesar de impossível, é também a condição de toda possibilidade: ela torna existente uma relação antes inexistente entre dois mundos, faz estes se encontrarem, levando o intelecto a redescobrir a si mesmo, a mudar de perspectiva e tornar-se outro. Língua e realidade, em suma, propõe uma ontologia do "vir a ser", isto é, do encontro entre realidades plurais por meio da tessitura demiúrgica das línguas.

Considerando que traduzir implica um salto impossível de um universo ao outro, o que também pode implicar uma abertura à conversação, este ensaio delineia uma breve tentativa de ensejar frutíferas traduções entre dois pensadores que, como espero ter mostrado, se insinuam mutuamente. Foucault buscou repensar o que já se sabe, e Flusser, multiplicar os pontos de vista. E em vez de chegarem a algum modelo de mundo, ambos insistiram em apontar como a realidade é dispersa, descontínua e plural, por mais coesa que pareça ser. A realidade é plural, com efeito, porque comporta muitas línguas - ou discursos, dispositivos, aparelhos, técnicas, modos de ser, etc. -, como um caleidoscópio que nos suscita questionamentos constantes: por que o mundo nunca permanece do mesmo modo? Quem pode falar e quem deve silenciar? Como vemos e como não vemos? Por que determinadas realidades são concebíveis e outras não?

Perguntas que não admitem senão respostas incompletas e, por isso mesmo, fluidas. Fluidez, materialidade e palavra como expressões do tecer, do perpassar, do realizar. 0 anverso flusseriano como o reverso foucaultiano - e um promissor vice-versa. 


\section{Referências}

CASSIN, Barbara. 0 efeito sofístico. São Paulo: Editora 34, 2005.

DELEUZE, Gilles; PARNET, Claire. Diálogos. São Paulo: Escuta, 1998.

DELEUZE, Gilles; GUATTARI, Félix. Mil platôs - Vol. 1. São Paulo: Editora 34, 1995.

DERRIDA, Jacques. A estrutura, o signo e o jogo no discurso das ciências humanas. In: DERRIDA, Jacques. A Escritura e a diferença. São Paulo: Perspectiva, 2009, p. 229-249.

JÚNIOR, Rafael M.; CAPELA, Carlos E. S. Entre língua e realidade: Vilém Flusser no reverso de uma urdidura estruturalista. Revista Eco Pós, Rio de Janeiro, v. 19, n. 1, 2016, p. 56-70.

FERREIRA, Debora P. Vilém Flusser, um filósofo da linguagem brasileiro.

Trans/Form/Ação, Marília-SP, v. 41, n. 2, p. 37-54, abr./jun., 2018.

FERREIRA, Maria Cristina L. 0 quadro atual da análise de discurso no Brasil. Letras: Revista do Programa de Pós-Graduação em Letras da UFSM, Santa Maria, n. 27, p. 39-46, 2003.

FLUSSER, Vilém. Ensaio para um estudo do significado ontológico da língua. Revista Brasileira de Filosofia, São Paulo, v. 12, n. 45, p. 69-90, jan./mar., 1962.

FLUSSER, Vilém. Língua e realidade. São Paulo: Annablume, 2007.

FLUSSER, Vilém. A história do diabo. São Paulo: Annablume, 2008.

FOSTER, Hal. 0 retorno do real: a vanguarda no final do século XX. São Paulo: Cosac Naify, 2014.

FOUCAULT, Michel. A arqueologia do saber. Rio de Janeiro: Forense Universitária, 2014.

FOUCAULT, Michel. As palavras e as coisas: uma arqueologia das ciências humanas. São Paulo: Martins Fontes, 2007.

FOUCAULT, Michel. Linguagem e literatura. In: MACHADO, Roberto. Foucault, a filosofia e a literatura. Rio de Janeiro: Jorge Zahar, 2005, p. 137-174.

FOUCAULT, Michel. A verdade e as formas jurídicas. Rio de Janeiro: Nau, 2002.

GÓRGIAS [Górgias de Leontinos]. 0 elogio de Helena. Lisboa: Imprensa Nacional Casa da Moeda, 2005.

MALDIDIER, Denise. A inquietação do discurso: (re)ler Michel Pêcheux hoje. Campinas: Pontes, 2003.

NIETZSCHE, Friedrich. Sobre a verdade e a mentira no sentido extra-moral. In: NIETZSCHE, Friedrich. Obras incompletas. São Paulo: Nova Cultura, 2000. 
POL-DROIT, Roger. Entrevistas con Michel Foucault. Buenos Aires: Paidós, 2008.

PRADO JR, Bento. A chuva universal de Flusser: resenha de "Ficções Filosóficas" de Vilém Flusser. Folha de São Paulo, São Paulo, 13 fev. 1999.

REBOUL, Olivier. Introdução à retórica. São Paulo: Martins Fontes, 2004.

\title{
Language and discourse in Flusser and Foucault: a lurking dialogue?
}

\begin{abstract}
This heuristic essay proposes a conceptual approximation between Flusser and Foucault, particularly between Flusser's first book and the so-called archaeological phase of Foucault. After a brief contextualization of the structuralist panorama to which they sought to respond, I present four "scenes", or thematic clippings, that prepare a dialogue that never existed. Dialogue is traced around the notion of the word as an irreducible matter from which the thoughts and the reality can exist. Finally, I argue that while Foucault aimed to denature the words, Flusser came to retranslate them as a way of amplifying the reality.
\end{abstract}

\section{Keywords}

Vilém Flusser. Michel Foucault. Language. Discourse. Poststruturalism.

Recebido em: 05/02/2019

Aceito em: 25/04/2019 